\title{
Corticosteroids in Experimental Fat Embolization
}

\author{
WILMONT R. KREIS, M.D.," S. MARTIN LINDENAUER, M.D., $\dot{\dagger}$ \\ AND THOMAS L. DENT, M.D. $\ddagger$
}

FAT EMBOLI WERE FIRST described by Zenker in 1862 [24]. Since that time all aspects of the phenomenon have been the subject of controversy. Fal embolization refers to the finding of fat particles in tissues (especially lung, kidney, and brain). The fat emboli syndrome is a clinical picture thought to be produced by severe fat embolization. Fat embolization is associated with a diverse variety of clinical problems but most commonly occurs with trauma, associated with fracture of the long bones.

Fat emboli are a common finding at autopsy following trauma. Sevitt reports an incidence of $89 \%$ [19]. However, the incidence of the fat emboli syndrome is much less. The exact incidence in significant trauma is difficult to ascertain due to difficulties in making the diagnosis and a lack of precise criteria as to what constitutes significant trauma.

Fat embolization has been implicated as the cause of death in individuals dying after trauma in $5-25 \%$ of cases $[18,24]$. Mortality is related to the severity of in-

\footnotetext{
* Resident in Surgery, University of Michigan Medical Center, Ann Arbor, Michigan.

$\dagger$ Professor of Surgery, University of Michigan Medical Center, Ann Arbor, Michigan.

¥ Assistant Professor of Surgery, University of Michigan Medical Center, Ann Arbor, Michigan.

From the Department of Surgery, Section of General Surgery, University of Michigan Medical Center, and Veterans Administration Hospital, Ann Arbor, Michigan.

Presented at the Sixth Annual Meeting of the Association for Academic Surgery, New Orleans, November, 2-4, 1972.
}

jury and the number of fat emboli per unit area of tissue examined at autopsy $[7,19]$. The fat emboli syndrome is most common in young males paralleling the incidence of severe trauma in this group [15]. Recently, investigators have proposed the use of corticosteroids as an adjunct to ventilatory assistance and other supportive measures in the treatment of pulmonary fat embolization $[3,9,21]$. This study was undertaken to cvaluatc the effects of corticosteroids in an experimental model of fat embolization.

\section{METHODS AND MATERIALS}

Sixteen mongrel dogs were anesthetized with intravenous sodium pentobarbital (30 $\mathrm{mg} / \mathrm{kg}$ ) and maintained with $4 \mathrm{mg} / \mathrm{kg} / \mathrm{hr}$ by continuous intravenous infusion. Animals were intubated and maintained on 20 cc $/ \mathrm{kg}$ of room air at 16 respirations per minute on a fixed volume respirator. Catheters were placed in the femoral artery and vein for pressure measurements and blood sampling. A Swan-Ganz flow dirceted catheter was passed into the pulmonary artery from the femoral vein for pressure measurements [20]. The animals were divided into four groups (Table 1). Fourteen animals received Oleic acid USP 0.07 $\mathrm{ml} / \mathrm{kg}$ intravenously at time zero. Seven of these animals (group 2) simultaneously received methylprednisolone $3 \mathrm{mg} / \mathrm{kg}$ intravenously. The other seven animals received an equivalent volume of normal saline (group 1). One animal received saline only (group 3), and one reccived only methylprednisolone (group 4). 
Table 1. Experimental and Control Groups

\begin{tabular}{cccll}
\hline Group & $\begin{array}{c}\text { Number } \\
\text { of dogs }\end{array}$ & \multicolumn{1}{c}{ Insult } & \multicolumn{1}{c}{ Treatment } \\
\hline 1 & 7 & Oleic Acid & Saline \\
2 & 7 & Oleic Acid & Methylprednisolone \\
3 & 1 & Saline & Saline \\
4 & 1 & Saline & Methylprednisolone \\
\hline
\end{tabular}

Table Q. Mean Arterial pH Determinations in Experimental Fat Embolization

\begin{tabular}{clllllll}
\hline & \multicolumn{7}{c}{ Time (hours) } \\
Group & \multicolumn{1}{c}{0} & \multicolumn{1}{c}{$1 / 2$} & \multicolumn{1}{c}{1} & \multicolumn{1}{c}{2} & \multicolumn{1}{c}{4} \\
\hline 1 & $7.46(.04)$ & $7.44(.02)$ & $7.40(.03)$ & $7.43(.03)$ & $7.46(.03)$ & $7.44(.02)$ \\
2 & $7.44(.05)$ & $7.45(.06)$ & $7.45(.06)$ & $7.45(.06)$ & $7.45(.04)$ & $7.45(.03)$ \\
3 & 7.45 & 7.45 & 7.45 & 7.44 & 7.44 & 7.44 \\
4 & 7.45 & 7.44 & 7.14 & 7.44 & 7.44 & 7.44 \\
\hline
\end{tabular}

Table 3. Mean Arterial PCO: in Experimental Fat Embolization*

\begin{tabular}{ccccccc}
\hline & \multicolumn{7}{c}{ Time (hours) } \\
Group & \multicolumn{1}{c}{0} & $1 / 2$ & 1 & 2 & 3 & 4 \\
\hline 1 & $24(3)$ & $25(3)$ & $27(4)$ & $25(4)$ & $24(3)$ & $25(4)$ \\
2 & $24(4)$ & $24(4)$ & $24(4)$ & $24(4)$ & $24(4)$ & $23(4)$ \\
3 & 28 & 28 & 28 & 28 & 29 & 29 \\
4 & 28 & 29 & 29 & 29 & 29 & 29 \\
\hline
\end{tabular}

* Millimeters of mercury.

Table 4. Mean Pulmonary Artery Pressure in Experimental Fat Embolization*

\begin{tabular}{|c|c|c|c|c|c|c|}
\hline \multirow[b]{2}{*}{ Group } & \multicolumn{6}{|c|}{ Time (hours) } \\
\hline & 0 & $1 / 2$ & 1 & 2 & 3 & 4 \\
\hline 1 & $20(0)$ & $18(1)$ & $18(1)$ & $20(1)$ & $22(1)$ & $22(1)$ \\
\hline 2 & $20(0)$ & $20(0)$ & $20(2)$ & $20(3)$ & $24(4)$ & $21(4)$ \\
\hline 3 & 20 & 20 & 18 & 18 & 24 & 22 \\
\hline 4 & 20 & 20 & 20 & 24 & 24 & 22 \\
\hline
\end{tabular}

* Centimeters of water.

Table 5. Mean Pulse Rate in Experimental Fat Embolization

\begin{tabular}{|c|c|c|c|c|c|c|}
\hline \multirow[b]{2}{*}{ Group } & \multicolumn{6}{|c|}{ Time (hours) } \\
\hline & 0 & $1 / 2$ & 1 & 2 & 3 & 4 \\
\hline 1 & $167(10)$ & $152(11)$ & $144(12)$ & $165(10)$ & $170(10)$ & $174(10)$ \\
\hline 2 & $160(11)$ & $145(13)$ & $148(8)$ & $150(8)$ & $149(10)$ & $144(8)$ \\
\hline 3 & 170 & 170 & 160 & 160 & 160 & 160 \\
\hline 4 & 175 & 175 & 170 & 170 & 160 & 160 \\
\hline
\end{tabular}

Pulse and arterial pressure were were collected before injection and $1 / 2,1$, measured and recorded with a Sanborn 2,3, and $4 \mathrm{hr}$ after injection and determinatransducer and recorder. Pulmonary artery tions of $\mathrm{PaO}_{2}, \mathrm{pH}$, and $\mathrm{PCO}_{2}$ obtained with pressure (PAP) was monitored with a a Radiometer blood gas analyzer. Chest water manometer. Arterial blood samples roentgenograms were obtained bef ore injec- 
Table 6. Mean Systemic Arterial Pressure in Experimental Fat Embolization*

\begin{tabular}{cllllll}
\hline & \multicolumn{6}{c}{ Time (hours) } \\
Group & \multicolumn{1}{c}{0} & $1 / 2$ & \multicolumn{1}{c}{1} & \multicolumn{1}{c}{3} & 4 \\
\hline 1 & $130(4)$ & $120(7)$ & $120(5)$ & $130(2)$ & $130(3)$ & $130(2)$ \\
2 & $135(10)$ & $125(4)$ & $126(6)$ & $129(6)$ & $131(3)$ & $129(6)$ \\
3 & 120 & 120 & 120 & 120 & 120 & 120 \\
4 & 125 & 120 & 125 & 125 & 120 & 125 \\
\hline
\end{tabular}

* Millimeters of mercury.

Table 7. Mean Arterial $\mathrm{PaO}_{2}$ in Experimental Fat Embolization*

\begin{tabular}{|c|c|c|c|c|c|c|}
\hline \multirow[b]{2}{*}{ Group } & \multicolumn{6}{|c|}{ Time (hours) } \\
\hline & 0 & $1 / 2$ & 1 & 2 & 3 & 4 \\
\hline 1 & $89(4)$ & $64(25)$ & $52(15)$ & $52(8)$ & $49(10)$ & $53(8)$ \\
\hline 2 & $89(4)$ & $80(15)$ & $71(15)$ & $71(13)$ & $74(10)$ & $74(10)$ \\
\hline 3 & 87 & 87 & 87 & 86 & 89 & 88 \\
\hline 4 & 86 & 89 & 88 & 90 & 88 & 89 \\
\hline
\end{tabular}

* Millimeters of mercury.

Table 8. Graph of Mean $\mathrm{PaO}_{2}$ ( \pm Standard Deviation) in Steroid Treated and Control Dogs Receiving Intravenous Oleic Acid

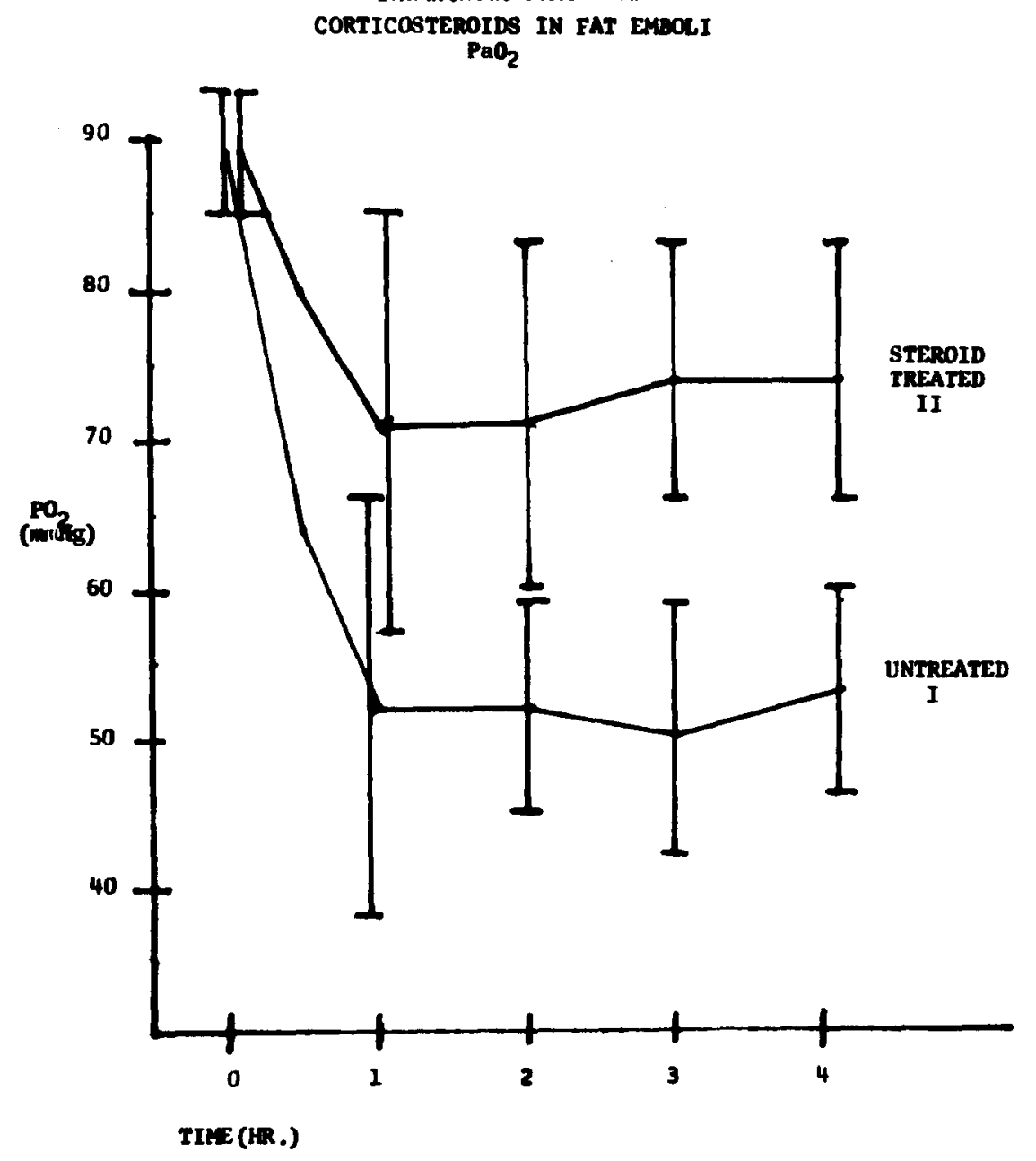




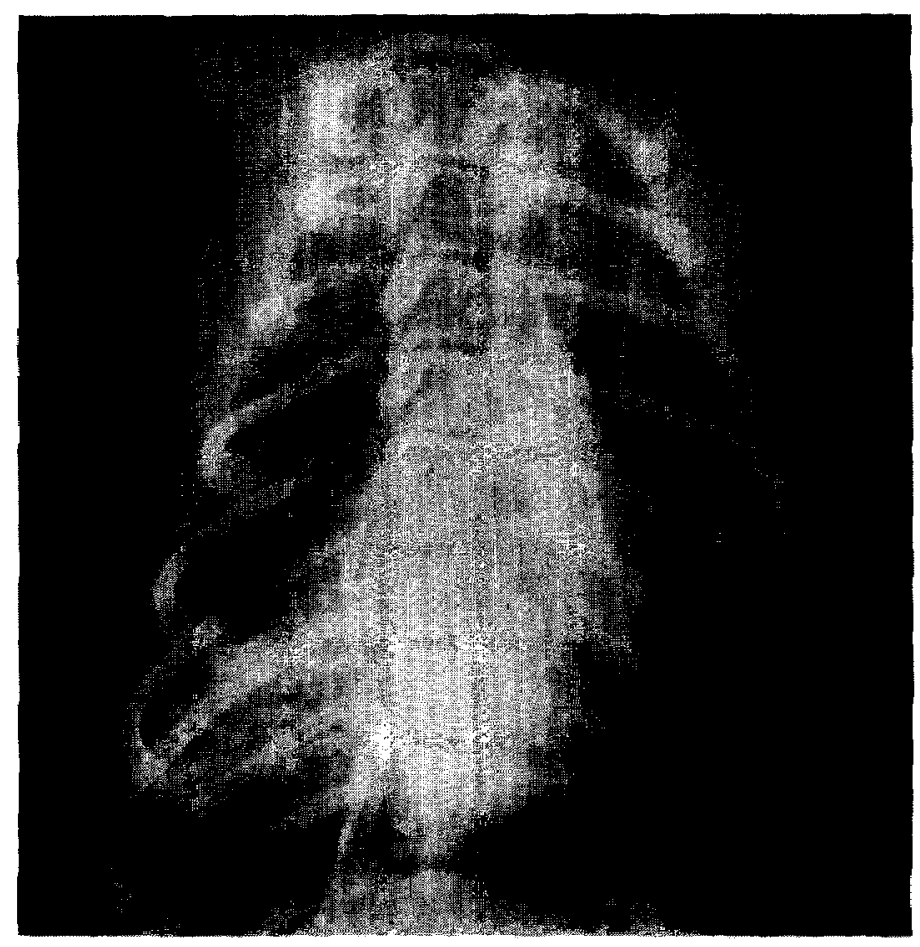

Fig. 1. Chest roentgenogram of untreated animal (group 1). Note diffuse patchy infiltrates.

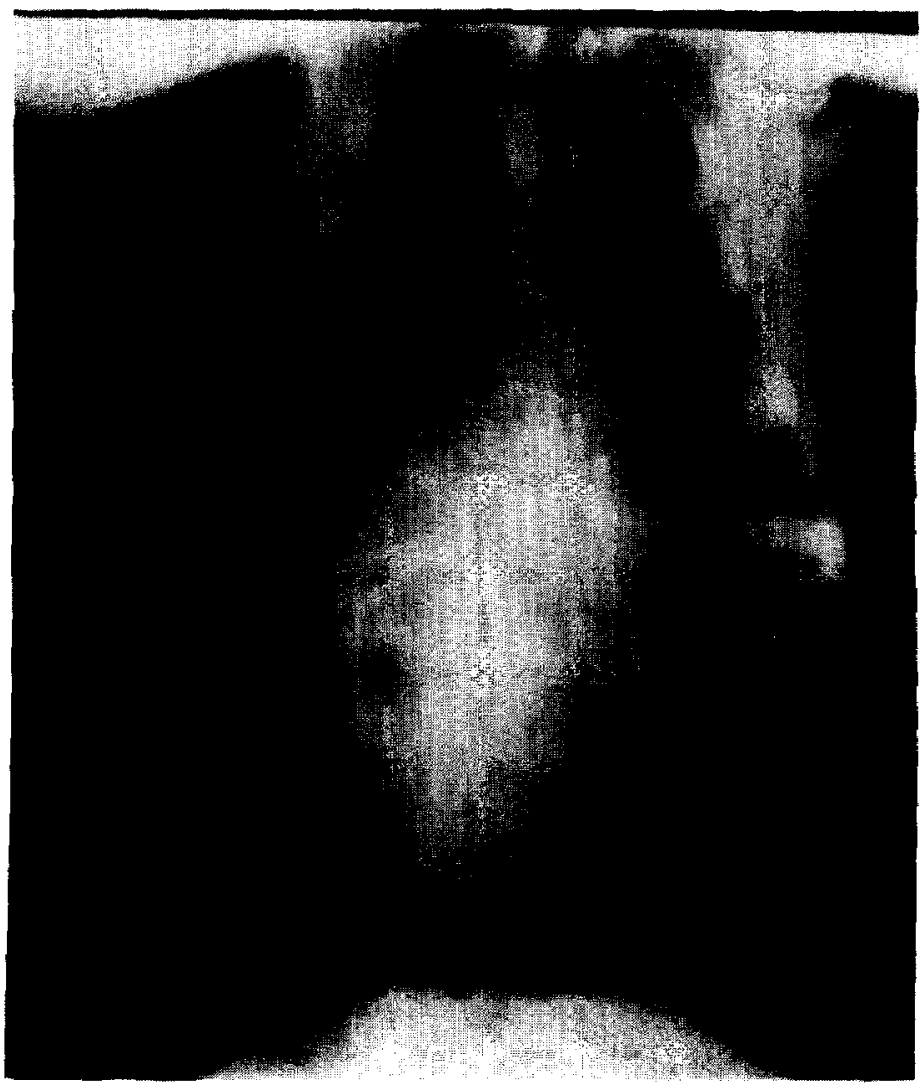

Fig. 2. Chest roentgenogram of steroid treated animal (group 2). Note relatively normal appearance. 


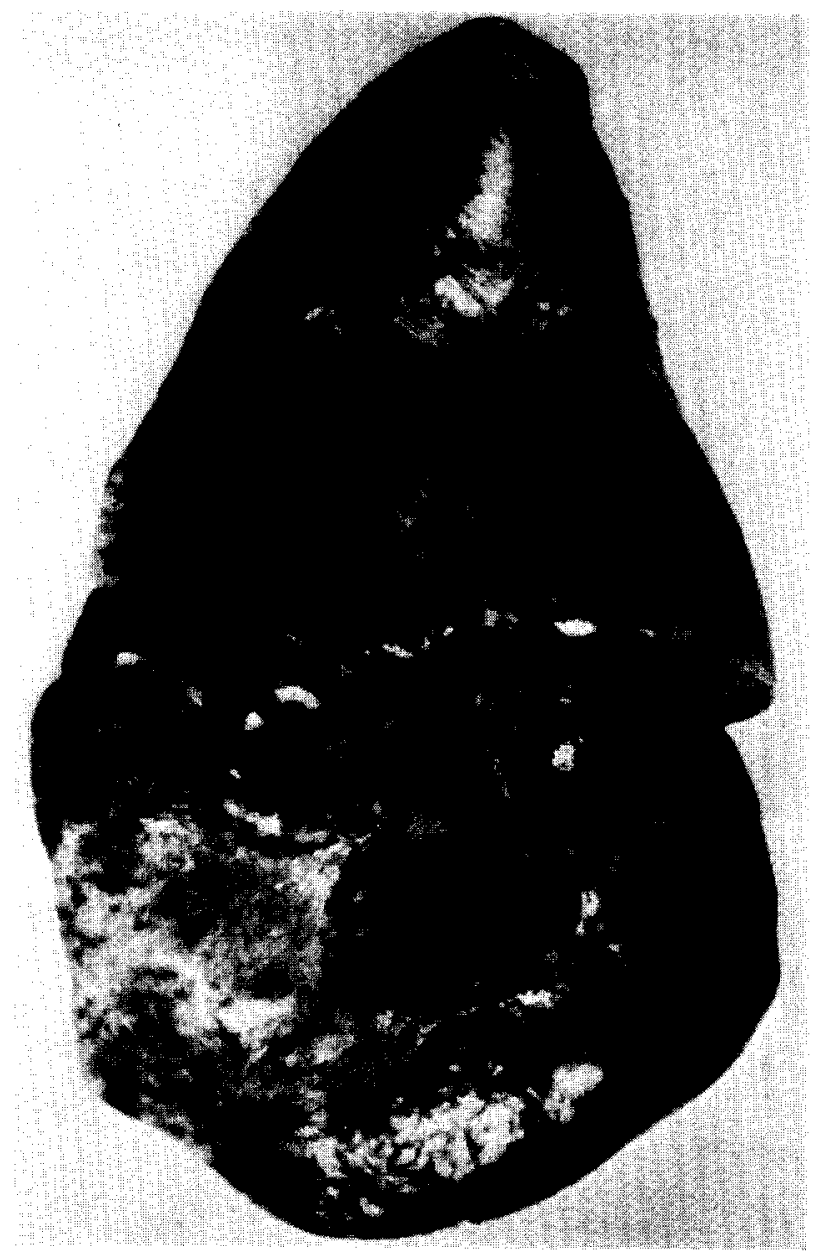

Fig. 3. Lung from untreated animal (group 1). There is marked congestion with focal hemorrhage.

tion and $3 \mathrm{hr}$ later. Animals were sacrificed at $4 \mathrm{hr}$ and sections of lung, brain, and kidney were subjected to gross and histologic examinations.

\section{RESULTS}

The arterial blood gas values, pulse, systemic arterial pressure and pulmonary artery pressures (PAP) are summarized in Tables 2-7. $\mathrm{pH}, \mathrm{PCO}_{2}, \mathrm{PAP}$, pulse, and arterial pressure were stable in all groups. For the duration of the experiment $\mathrm{PaO}_{2}$ (Table 8) showed a marked and sustained decrease in group 1 (oleic acid only). The decrease in $\mathrm{PaO}_{2}$ was significantly less marked in group 2 (steroid treated ani- mals). There was no change in group 3 and 4 animals.

In group 1 animals chest roentgenograms taken at $3 \mathrm{hr}$ showed diffuse infiltration in both lung fields (Fig. 1). These changes were either very mild or absent in the steroid treated group 2 animals (Fig. 2). Chest roentgenograms were normal in group 3 and 4 animals.

Grossly, the lungs in group 1 animals were markedly congested with focal areas of hemorrhage (Fig. 3). The steroid treated animals (group 2) showed some passive congestion but to a much lesser degree than in the untreated animals (Fig. 4). Histologically, the nonsteroid treated animals 


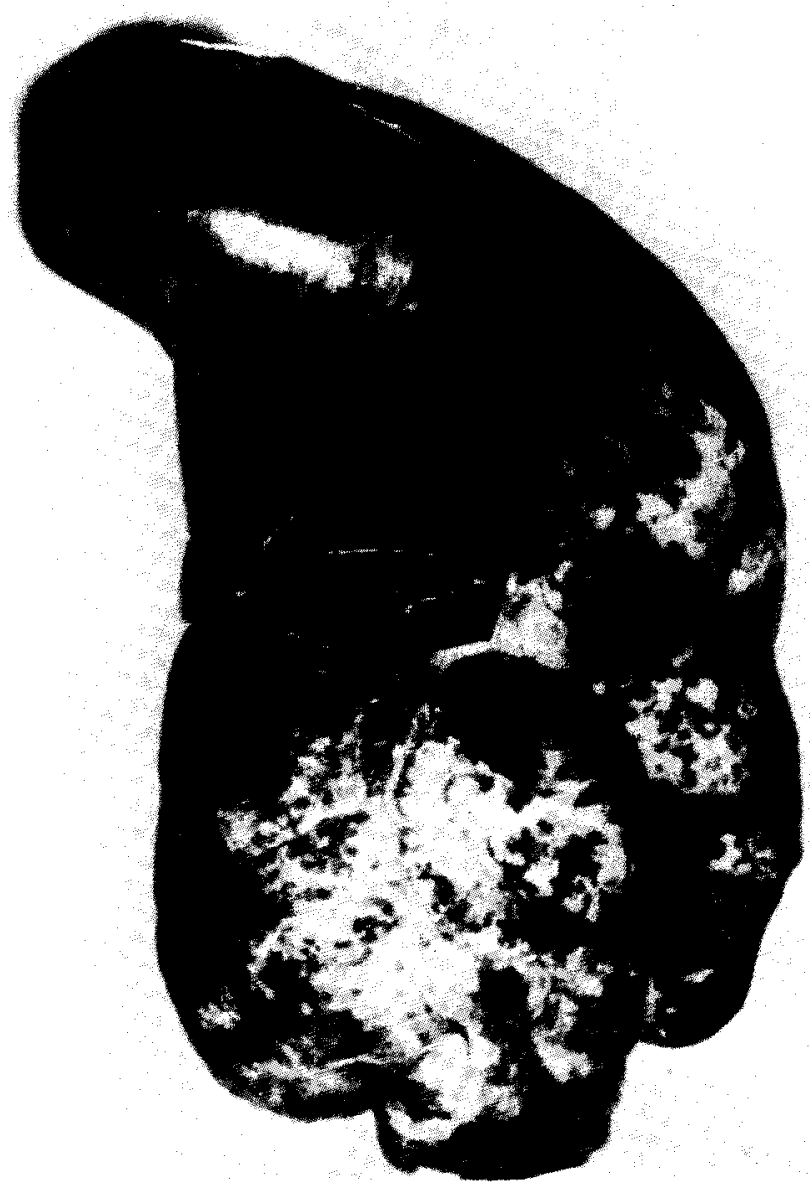

Fig. 4. Lung from treated animal (group 2) shows much less congestion.

(group 1) showed marked edema and congestion with focal areas of hemorrhage and inflammation (Fig. 5). The steroid treated animals (group 2) showed mild congestion and focal mild edema (Fig. 6). The lungs in group 3 and 4 animals were normal grossly and histologically. Brain and kidney sections were normal grossly and histologically in all groups.

\section{DISCUSSION}

Peltier has suggested the following course of events in the pathogenesis of fat emboli: emboli of neutral fat lodge in the pulmonary arterioles and capillaries; lung lipase hydrolyzes the neutral fat with the release of free fatty acids; the free fatty acids which are quite toxíc cause local in- flammation, congestion, and edema, which is responsible for the hypoxia always present in clinical fat embolism [14].

The use of corticosteroids in the treatment of respiratory distress associated with fat embolism was proposed by Ashbaugh and Petty in 1966 [3]. They felt that steroids might inhibit the local pulmonary inflammatory reaction, improve local blood flow and decrease the respiratory distress associated with clinical fat embolism. Recently Fischer et al. reported using large doses of corticosteroids in 13 patients with respiratory distress syndrome associated with fat emboli [9]. They noted that although $\mathrm{PaO}_{2}$ improved soon after the administration of steroids, compliance did not improve until up to $\mathbf{7 2} \mathrm{hr}$ latcr. They pro- 


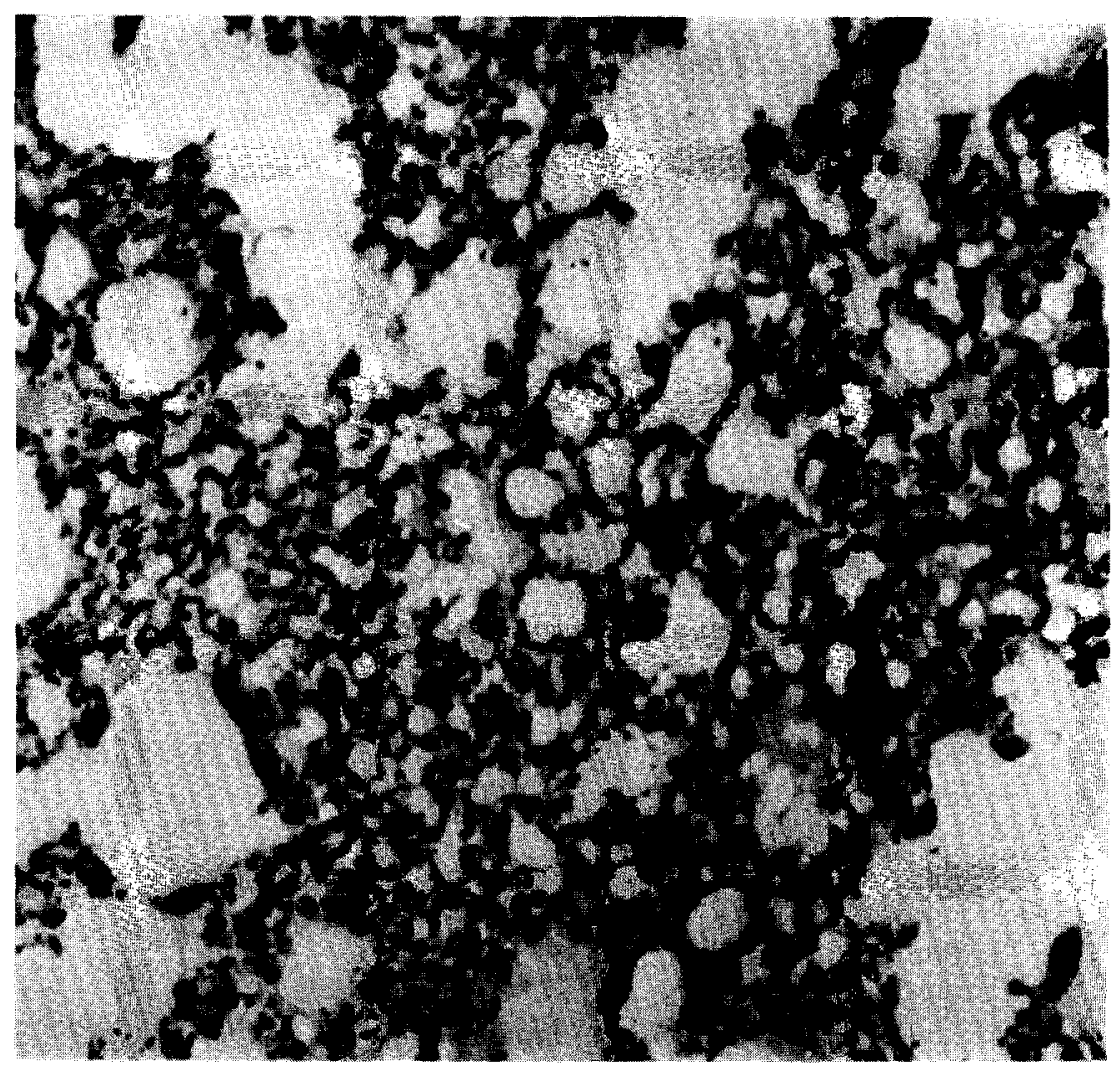

Fig. 5. Photomicrograph of lung tissue from untreated animal (group 1). There is marked edema congestion and leucocytic infiltrate. Hematoxylin and eosin. Original magnification $\times 200$.

posed that platelets became adherent to fat particles that lodge in the lung vasculature and that serotonin and other amines are released from the platelets causing pulmonary arterial spasm and abnormal ventilation-perfusion ratios. They suggested that steroids counteract the affect of these amines and improve the ventilation-perfusion ratio and improve $\mathrm{PaO}_{2}$. However, it is not until the edema fluid and cellular exudates are resorbed (over a period of a few days) that compliance returns to normal. This mechanism has also been advocated by Moritz et al. who have shown that reserpine pretreatment to deplete platelet (and other) stores of serotonin and other humoral agents results in a less severe response to experimental fat embolism [13].

Wertzberger and Peltier [21] showed a decrease in the mortality of rats undergoing experimental fat embolization when treated with large doses of steroids. They proposed that the steroids were beneficial for their anti-inflammatory properties and their ability to modify tissue response to injury in conditions associated with capillary permeability.

The period of time between the lodgment of neutral fat particles in the lung and the release of sufficient free fatty acids to cause the inflammatory changes necessary to result in respiratory symptoms may represent the symptom free interval seen between the external trauma and the respiratory distress associated with fat embolism [14]. The animal model used in this study avoids this interval by the direct administration of a free fatty acid. Oleic acid is the most abundant unsaturated free fatty acid in the bones and soft tissues $[14,16]$. A number 


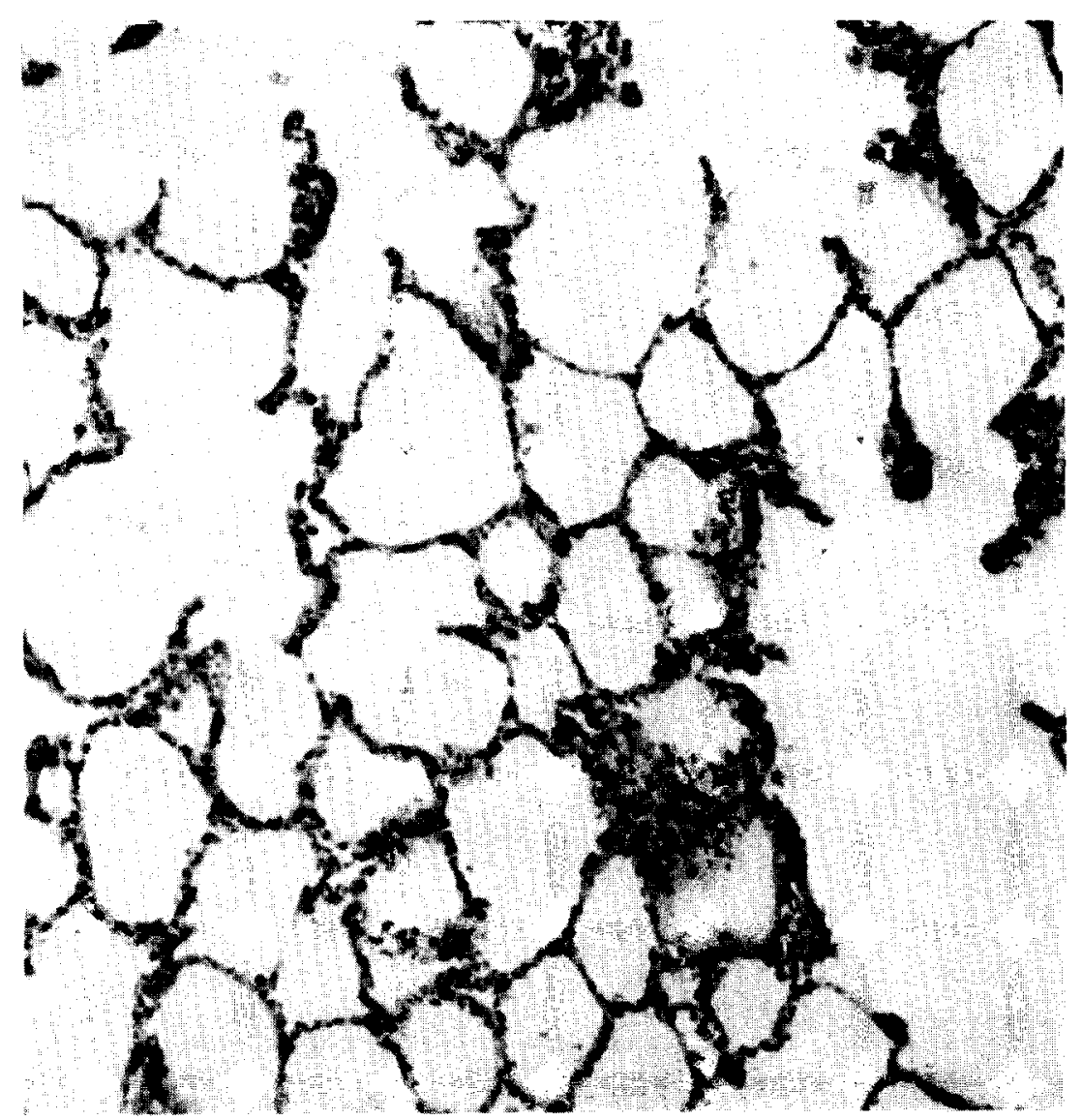

Fig. 6. Photomicrograph of lung tissue from animal treated with corticosteroids (group 2). There is minimal edema and cellular infiltrate. Hematoxylin and eosin. Original magnification $\times 200$.

of investigators have studied this particular model of pulmonary fat embolism and found that it results in a pathologic and clinical picture entirely similar to that seen in humans with respiratory insufficiency due to fat embolism (i.e., decreased $\mathrm{PaO}_{2}$, roentgenographic changes, congestion, edema, and hemorrhage in the lung) $[2,4$, $6,12]$.

The diagnosis of clinical fat embolism is often difficult and the various diagnostic techniques utilized are not entirely satisfactory $[8,11,15,19,22,23] . \mathrm{PaO}_{2}$ reliably reflects the severity of respiratory distress and is of great value in following the progress of patients with pulmonary fat embolism [9, 22, 23]. Chest roentgenograms are less reliable but generally provide some measure of the severity of pulmonary fat embolization and are a good means of following patients' clinical progress $[1,8,9$, $22,23]$. Pulmonary artery pressure has been reported to be elevated in experimental pulmonary fat embolism [4] but has not been adequately investigated clinically.

In this study animals treated with oleic acid showed a picture similar to the respiratory distress in patients with pulmonary fat embolism. There was a marked decrease in $\mathrm{PaO}_{2}$, roentgenographic changes compatible with fat embolism were observed and inflammation, edema, congestion, and hemorrhage were present in the pulmonary parenchyma.

The animals treated with steroids showed significantly less marked changes in all of the above. The $\mathrm{PaO}_{2}$ decreased less, the 
roentgenograms showed mild or no changes, and tissue changes were less marked both grossly and histologically. These results suggest that massive corticosteroid therapy may be a valuable adjunct to ventilatory support in the treatment of the respiratory distress associated with fat emboli and support the clinical observations of the beneficial effect of corticosteroids.

\section{SUMMARY}

Adult mongrel dogs were given intravenous oleic acid in an experimental model of pulmonary fat embolism. The changes in $\mathrm{PaO}_{2}$, chest rocntgenograms, and pulmonary tissues were less marked when high doses of corticosteroids were administered.

\section{REFERENCES}

1. Acker, S. and Greenberg, II. Pulmonary injury from post traumatic fat emboli (clinical and roentgenologic features). Amer. Rev. Resp. Dis. $97: 423,1968$.

2. Ashbaugh, D. and Takeshi, U. Respiratory and hemodynamic changes after injection of free fatty acids. $J$. Surg. Res. 8:417, 1968.

3. Ashbaugh, D. and Petty, T. Use of corticosteroids in treatment of respiratory failure associated with massive fat emboli. Surg. Gynecol. Obstet. 123:493, 1966.

4. Baker, P., Kuenzig, M. and Peltier, L. Experimental fat emboli in dogs. J. Trauma 9:577, 1969.

5. Bradford, D., Foster, R. and Nossel, H. Coagulation alterations, hypoxemia, and fat emboli in fracture patients. $J$. Trauma 10:307, 1970.

6. Bruecke, P., Lam, K., Shannon, D. and Kazemi, H. The pathophysiology of pulmonary fat emboli. J. Thorac. Cardiovasc. Surg. 61 :949, 1971.

7. Emson, H. Studies in 100 patients dying after injury. J. Clin. Pathol. $11: 28,1958$.

8. Evarts, C. Diagnosis and treatment of fat emboli. JAMA 194:899,1965.
9. Fischer, J., Turner, R., Herdon, J. and Riseborough, E. Massive steroids in severe fat emboli. Surg. Gynecol. Obstet. 132:667, 1971.

10. Fuchsig, P. A new clinical and experimental concept in fat emboli. N. Engl. J. Med. 276:1192, 1967.

11. Haas, J., Dekker, A., Pèrri, J. and Mankin, H. Fat in the CSF, possible significance in diagnosis of fat emboli. J. Trauma 8:593, 1968.

12. King, E., Weily, H., Genton, E. and Ashbaugh, D. Consumption coagulopathy in the canine oleic acid model of fat emboli. Surgery 69:533, 1971.

13. Moritz, E., Border, J., Schueller, E. and Schenk, W. Experimental pulmonary fat embolism: Beneficial effects on pulmonary function by reserpine pre-treatment. Ann. Surg. (in press).

14. Peltier, L. Collective review: An appraisal of the problem of fat embolism. Int. Abstr. Surg. 104:313, 1957.

15. Peltier, L. and Scott, J. Fat emboli. Surgery 42:541, 1957 .

16. Peltier, L., Wheeler, D., Boyd, II. and Scott, J. Fat emboli I, II, III. Surgery. 40:657. 661. $665,1956$.

17. Peltier, L. Fat emboli: A pulmonary disease. Surgery 62:756, 1967.

18. Robinson, E. Effects of shock upon initial blood gas data in experimental fat emboli. J. Trauma 10:299, 1970.

19. Sevitt, S. Fat Emboli. Butterworth, London, 1962.

20. Swan, H., Ganz, W., Forrester, J., Marcus, H., Diamond, G. and Chonette, D. Catheterization of the heart. N. Engl. J. Med. 283:447, 1970.

21. Wertzberger, J. and Peltier, L. Fat emboli: Effect of corticosteroids on experimental fat emboli in rats. Surgery 64:143, 1968.

22. Wertzberger, J, and Peltier, L. Fat emboli: Importance of arterial hypoxia. Surgery 63:626, 1968.

23. Wright, B. Diagnostic features of fat emboli in six cases. Anesthesiology 34:290, 1971.

24. Zenker, F. Beitrage zu Normalen und Pathologischen Anatomie der Lange, p. 31. J. Braunsdorf, Dresden, 1862. 